\title{
The political economy of regional grants in Peru
}

\author{
Leonardo E. Letelier S. and Gonzalo Neyra A.
}

ABSTRACT

This paper explores the regional allocation pattern of general resources (recursos ordinarios) in Peru, which are distributed to regional governments through a discretionary grant by the national government. We estimate an empirical model based on a panel of annual data between 2004 and 2010. Although national transfers are significantly biased towards regions where the national government received the lowest electoral support, the data suggest that this effect is strongest at the beginning of the administration's period in office. In the long run, however, opposition regions appear to host more volatile constituencies, which is compatible with the swing-voter hypothesis. Interestingly, regions that strongly supported the president receive the fewest benefits. Finally, the role of regional conflicts, the effect of lobbying by organized regionally based civil groups and the size of the regional constituency, among others variables, are statistically significant in the estimations.

H77, D72, D78

Gonzalo Neyra A. is a researcher with the Economic and Social Research Consortium (cies). gneyra@cies.org.pe 


\section{I}

\section{Introduction}

This article explores the dynamics of grants to regional governments in Peru. It provides empirical support to the hypothesis that the central government's decisions about transfers to regional governments respond, at least partially, to political opportunism. Following similar studies for other countries, we examine the territorial distribution of general resources (called recursos ordinarios in Peru), which account for more than $70 \%$ of all transfers to regions. Since this fund is allocated on a discretionary basis, the national government has considerable leeway to use the grants to generate political returns.

The theoretical background on the subject is twofold. On the one hand, a normative set of policy recommendations conceive intergovernmental transfers as a way of correcting the potential resource misallocation caused by interjurisdictional externalities, the response to the need for national standards in public goods and the way to address interjurisdictional equity goals and a number of other national welfare goals. On the other, the political economy approach stresses potential deviations from national welfare targets as a result of the central government's use of grants as a pork barrel political device. The literature is divided, however, regarding the most likely strategy to be used by governments when allocating grants. The two most common views are the swing-voter approach (Lindbeck and Weibull, 1987 and 1993) and the aligned-region hypothesis (Cox and McCubbins, 1986).

This article argues that Peru provides a fertile ground for machine politics. As in other Latin American countries, the political scenario is difficult to predict over time, and the mechanisms for social monitoring of the government's behaviour are relatively weak, which facilitates taking larger spoils from office. Moreover, the clear dissociation between national versus regional political parties in Peru makes it difficult to link the two tiers of government through a mutually rewarding strategy. This has two implications. First, short-term motives are likely to carry the most weight in decisions about which regions and functionaries are to receive discretionary grants. This situation promotes giving larger transfers to more risky and politically profitable regions, where the local constituency is highly volatile. Second, the national government's predominant strategy minimizes the potential danger of giving support to rising regional leaders and thereby maximizes the benefit in terms of votes from less supportive regional constituencies. To explore these issues, we build an empirical model of the national government's transfer allocation strategy, using a panel data set covering the period from 2004 to 2010, to identify the main factors in the regional distribution of general resources. While a set of normative considerations are properly accounted for in the empirical model, the results are generally in line with the aforementioned hypotheses.

The rest of the article is organized as follows. Section II examines the theoretical and empirical literature. Section III describes political institutions and the existing regional funding mechanism in Peru. The empirical model, the estimation approach and the data description are reported in section IV. Our econometric results are shown in section V, and section VI presents the main conclusions.

\section{II}

\section{Theory and existing empirical evidence}

The "public economics" explanation of the behaviour of intergovernmental grants clearly distinguishes two approaches. One is purely normative, as it stresses the view that the donor tier of government follows some kind of national utility function (Musgrave, 1958). Just as typical market failures impede competitive markets from achieving an efficient resource allocation for private goods, subnational governments can make suboptimal decisions about which type and how much of specific public goods are to be provided. Externalities between jurisdictions place a wedge between national and jurisdictional marginal benefits (or costs) (Oates, 1972). The need for national standards, the implicit (or explicit) principal-agent relationship between central 
and subnational governments, the aim of having a more equitable revenue distribution across the national territory and the achievement of an efficient countrybased resource allocation, are all normative justifications for grants (Buchanan, 1950; Inman, 1988; King, 1991; Letelier, 2012). The second explanation, based on the "public choice" approach, states that national fiscal decisions will be shaped by the preferences of what is known as the median voter. This implies that any grant allocation has to follow the demands and geographical distribution of the median voter (Boex and MartínezVásquez, 2010).

Grants can also be analysed from a political economy perspective. A number of studies of the New Deal experience in the United States, where significant grants were allocated to jurisdictions hit hard by the Great Depression, question the assumption that federal grants really targeted jurisdictions in need (Arrington,1970; Reading, 1973). Wright (1974) finds a systematic correlation between federal expenditures per capita and states' votes during the New Deal period. Similar results are found by Inman (1988) and Couch and Shughart (1998), among others. These studies generally show that normative arguments for justifying federal grants to states fall short of the facts, suggesting that redistributive politics played a significant role. This last behaviour is commonly known as a "pork barrel" policy, and it raises the potential for misallocation of public funds when government grants are allocated on a discretionary basis. ${ }^{1}$

If we assume that national grants to regions respond at least partially to political economy considerations and that voter preferences are self-motivated, then the key issue to be addressed hinges on the type of regional voters who are more likely to be given larger allocations. Two competing views have been put forwards in the literature (Cox, 2010). First, the swing-voter hypothesis states that regions where a significant number of voters are undecided are the most politically attractive areas (Lindbeck and Weibull, 1987 and1993). Case (2001) finds evidence of such a pattern in federal grants to local governments in Albania. Milligan and Smart (2005) show similar evidence for federal grants to the five poorest Canadian provinces. Castells and Solé-Ollé

\footnotetext{
1 As Grossman (1994) correctly points out, formula-driven grants may also be politically motivated insofar as the formula itself is defined by the national government. Nevertheless, while this may occur over long periods of time, if the formula can be actually changed, it becomes more likely that purely discretion-based allocations will be especially responsive to pork barrel political considerations.
}

(2005) conclude that swing voters matter when it comes to the allocation of central government grants to regional governments for infrastructure in Spain. Additional evidence is provided by Wallis (1998) and Gamkhar and Ali (2007) for the United States, Dahlberg and Johansson (2002) and Johansson (2003) for Sweden and Gonçalves (2010) for Portugal. For Peru, Schady (2000) provides some weak (albeit consistent) evidence in favour of the swing-voter hypothesis in a study of the National Social and Development Compensation Fund (FONCODES), which was discretionally allocated to provinces in the early1990s.

The second view is that transfers will be allocated mostly to regions where the national government has the highest support. This is the aligned-region hypothesis, which suggests that no clear-cut political economy rationale can be found to explain why central governments would be equally generous with aligned and non-aligned regions. Cox and McCubbins (1986) contend that candidates' promises to their constituencies are made in the context of the classic trade-off between political returns and risk. If politicians are risk-averse (as they probably are) and swing voters are riskier than aligned voters in terms of political return, then grants are more likely to be given to aligned voters. Supporting evidence is provided by Solé-Ollé and Sorribas (2008) in the case of Spanish municipalities. For the United States, the cases of federal grants to states (Grossman, 1994) and federal grants to local governments (Ansolabehere and Snyder, 2006) appear to favour this hypothesis. Similar results were obtained by Biswas, Marjit and Marimoutou (2010) for federal grants to states in India. Interestingly, Hanes (2007) finds that only socialist central government coalitions (as opposed to conservative ones) appear to be more sensitive to vote purchasing among municipalities with a high socialist share of voters in Sweden. Gonçalves (2010) concludes that European funds geared to Portuguese local governments are skewed to municipalities where the local ruling political coalition is more strongly supported. For Peru, Schady (2000) concludes that more resources were given to aligned provinces and to those where political support for the government in office declined relative to the last presidential elections. In opposition to the alignedregion hypothesis, Segura-Ubiergo (2007) and Graham and Kane (1998) show clear stylized facts suggesting that throughout the term in office of President Fujimori (1990-2001), social grants were discretionally directed to areas where the ruling government won the least support in the 1993 referendum. 
Some efforts have been made to bridge the gap between these approaches. Dixit and Londregan (1996) state that if parties are equally able to levy taxes on all groups but are more efficient in benefiting their own constituency, then machine politics will dominate, and more money will be channelled to supportive groups. Swing regions will be given higher benefits when parties are equally efficient in benefiting all groups, so that parties' vote-maximizing behaviour is consistent with targeting moderate groups with loose ideological attachments. In a follow-up paper, Dixit and Londregan (1998) show that in a world of equity-concerned voters, middle-class groups become more politically attractive, given their higher concentration of flexible voters. Another brand of theoretical research uses the traditional portfolio theory to explore how politicians allocate money across regions so as to maximize rents subject to varying degrees of risk from various assets (Díaz-Cayeros, Estévez and Magaloni, 2008; DíazCayeros, 2008).

Another strand of literature stresses the potential impact of interest groups in making the national government more sensitive to their demands (Olson, 1965). While economic redistribution is involved in almost every aspect of the political process, singling out specific groups can be construed as a tactical (or pork barrel) redistribution or even as an attempt to buy votes from those most likely to sell them (Anderson and Tollison, 1988). Support for this hypothesis in the context of the national government's allocation of transfers has been found by Grossman (1994) and Gamkhar and Ali (2007) for the United States, Porto and Sanguinetti (2001) for Argentina and Biswas, and Marjit and Marimoutou (2010) for India.

The dynamic implications of pork barrel politics may also be relevant. Political business cycle theory (Rogoff and Sibert, 1988; Rogoff, 1990) suggests that the magnitude of grants being used as a tactical device will increase in the years leading up to a national election to raise the chances of the incumbent's re-election. Numerous studies support the existence of such a cycle (for example, Drazen, 2000). The Peruvian case, in particular, seems to conform to this pattern. Schady (2000) finds that expenditures under FONCODES increased significantly before elections. Carranza, Chávez and Valderrama (2007) look at the period from 1970 to 1995; they conclude that the combination of strong presidentialism and a fragmented political scenario in Peru have favoured the use of government expenditure as a re-election device.

\section{III}

\section{Political institutions and regional funding in Peru}

\section{The political map in Peru}

Peru has a multi-party political system in which different parties often form alliances to improve their electoral chances. One of the most important parties during our sample period (2004-2010) was the Revolutionary Popular Alliance (APRA), which promotes a social democratic ideology with a clear-cut pro-decentralization discourse. In contrast to other political forces, APRA is a well-organized party, and it is the only national party with strong roots at the regional and municipal levels. Three other parties were also important during this period: Possible Peru, a centre-left party founded in 1994 by Alejandro Toledo; the Christian People's Party, a centre-right party dating back to the 1960s (which has some congressional representation, but has never won a presidential election); and the Alliance for the Future, which was formed by the merger of two pro-Fujimori parties (Change 90 and New Majority). After the end of our sample period, the formerly small Peruvian Nationalist Party had become a strong force by winning the 2011 presidential election.

The decentralization process in Peru received a major boost in 1989, when Alan García — an APRA-supported president- created 12 regions with elected regional presidents. However significant, this important step was temporarily reversed by García's successor, Alberto Fujimori, who carried out a military-supported presidential coup in 1992, in which he suspended the constitution, shut down the national Congress and blocked political regional autonomy. A new constitution was adopted in 1993, wherein former regional governments were 
supplanted by administrative branches of the presidency called Transitory Councils of Regional Administration (Bensa, 2002). After Fujimori's downfall in 2000, the Congress itself elected a new transitory government which called for presidential and congressional elections. The new national Congress was to be composed of regionally represented members.

Fujimori was succeeded by Alejandro Toledo, a Possible Peru candidate who came into power in 2001 following a very tight election. In an attempt to dampen APRA leadership, Toledo launched a pro-decentralization constitutional reform in April 2002. Regional presidential elections were held in November of that year, in which 24 regional governments were appointed (Tanaka, 2002). Although no Possible Peru candidates were elected, 12 APRA-supported regional governments came into power. In July 2006, Alan García was elected national president for a second term, and regional elections were held in November of that year. APRA lost 12 regional governments in that election, ending up with only two representatives. Understandably, budget-approved transfers to regions by García's government were sharply cut from 2006 to 2007.

Political representation at the regional level is based on the simultaneous appointment of the regional president, vice-president and regional council for a fouryear period. A similar system holds at the municipal level. Peru is currently divided into 25 regional governments, including the El Callao Constitutional Province (which has regional status) and 1,828 municipal governments. Twelve regions were in opposition to the national government between 2003 and 2006. ${ }^{2}$ Only two of them kept the same regional government and ruling political party after the 2006 national election. This shows a highly volatile constituency among these regions, which provides relevant information as to where the swing voters are located.

\section{Regional funding}

With the exception of some minor income from regionally provided services, regions in Peru have very few revenues of their own (Vega, 2008). Most resources come from two main fiscal transfers from the national government: earmarked resources (recursos determinados) and general resources (recursos ordinarios). The first source is fed by taxes on the extractive industry, of which the mining canon is the most important. A small share of import taxes is also given to regions under this grant, but only Callao receives any. A distinguishing feature of earmarked resources is that they are allocated according to a well-specified formula that benefits only naturalresource-producing regions. Given that natural resources are very unevenly distributed across the territory, this tax-sharing scheme results in a very inequitable regional allocation. About $80 \%$ of the State's mining revenues is absorbed by one third of all regions (Vega, 2008). Moreover, not all transfers in this category are given to regional governments, but rather are shared with municipalities and local universities.

In contrast to the earmarked resources, general resources are assigned on a discretionary basis. They originate from national general tax revenues and have no link to specific public entities. At the beginning of the decentralization process, regional governments were made automatically responsible for a much larger share of national public revenues. This led the Ministry of Economy and Finance to introduce regional transfers as a new budget item in 2003, although general resources are not formally included under the existing institutional framework. A feasible interpretation of the Fiscal Decentralization Law suggests that general resources should be conceived as a transitory device for supporting the regions, until some specific taxes are legally committed to regional control. For now, no specific rule precludes general resources from being assigned discretionally across regions, which then use the funds to finance both their staff and local investment. In recent years, an increasing share of regional investment is being funded through earmarked resources, leaving general resources to cover most current expenditures.

Total transfers to all subnational governments (including municipalities) rose from $27 \%$ of the general government's budget in 2005 to $37 \%$ in 2011 (see table 1). There were three main reasons for this sharp rise. First, some new functions were delegated to the regions over the period under analysis. Second, non-discretional transfers grew considerably as a result of a surge in the price of gold, copper and oil over the sample period. Third, the robust growth of the Peruvian economy over the period further contributed. Although the Ministry of Economy and Finance is involved in decision-making on the distribution of regional grants, a large share of general resources comes from the general government budget. This, together with the regions' lack of funding, has tended to reinforce the use of political negotiations as a major factor in allocating this money.

2 That is, they had less than $50 \%$ support for the national government. 
TABLE 1

Transfers to subnational governments in Peru

\begin{tabular}{|c|c|c|c|c|c|c|c|}
\hline Type of transfer & 2005 & 2006 & 2007 & 2008 & 2009 & 2010 & 2011 \\
\hline Total general government budget (billions of dollars) & 17.64 & 19.45 & 22.51 & 27.69 & 27.70 & 31.76 & 33.63 \\
\hline Transfers to all subnational governments (billions of dollars) & 4.80 & 5.47 & 6.79 & 9.97 & 11.03 & 11.48 & 12.30 \\
\hline Transfers as a percentage of general government budget & 27.00 & 28.00 & 30.00 & 36.00 & 40.00 & 36.00 & 37.00 \\
\hline Total transfers to regional governments(billions of dollars) & 1.67 & 2.04 & 2.94 & 4.543 & 4.97 & 5.581 & 5.35 \\
\hline General resources (billions of dollars) & 1.46 & 1.67 & 2.171 & 3.41 & 3.66 & 4.06 & 4.03 \\
\hline General resources as a percentage of regional transfers & 87.00 & 82.00 & 74.00 & 75.00 & 74.00 & 73.00 & 75.00 \\
\hline Earmarked resources (billions of dollars) & 0.21 & 0.37 & 0.77 & 1.13 & 1.31 & 1.52 & 1.32 \\
\hline Earmarked resources as a percentage of regional transfers & 13.00 & 18.00 & 26.00 & 25.00 & 26.00 & 27.00 & 25.00 \\
\hline
\end{tabular}

Source: authors' elaboration, on the basis of the annual General Budget Law of the Republic of Peru.

\section{IV}

\section{Hypothesis testing}

\section{The empirical model}

Our hypothesis is that the national incumbent's behaviour as far as grant allocation is concerned is generally determined by a combination of sociodemographic $(S D)$, economic $(E C)$ and political $(P O L)$ factors. We assume that the government's potential opportunistic bias is restricted by various environmental factors. First, there is an institutional framework that limits the chance of grants being used for electoral purposes. Second, all political coalitions respond, at least partially, to the will of the median voter. Third, ideology usually matters. Thus, our empirical panel model is expected to be represented by equation (1), where $r$ represents the region and $t$ time:

$$
\begin{aligned}
\text { grant }_{r t}= & \alpha+\beta_{1} \times P O L_{r t}+\beta_{2} \times E C O N_{r t}+ \\
& \beta_{3} \times S D E M_{r t}+{ }_{r t}+\varepsilon_{r t}
\end{aligned}
$$

A key variable to discriminate between the swing-voter and aligned-region hypotheses is the degree of regional political support for the national government in office. As in most empirical papers on this topic, we explore two related variables. The first is the share of each regional constituency that voted for the national government in office (ng.votes). A positive effect indicates that aligned regions are being favoured. Second, some studies identify swing regions as being close to $51 \%$ in support of the national government. This share of votes is called marginal votes (marvotes). Both variables are timed by the regional constituency.
The following outcomes may be expected: (i) if

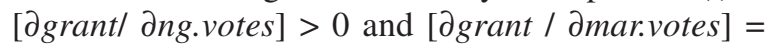
0 , aligned voters are assumed to predominate when deciding the assignment of grants; (ii) if [jgrant/ $\partial n g$. votes $]=0$ and $[$ grant/ $\partial$ mar.votes $]<0$, it follows that swing regions are being favoured; and (iii) if [jgrant/

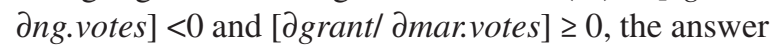
depends on the composition of the region's voters. A volatile constituency among low ng.votes regions (which are the most favoured in this case) indicates that swing voters are being targeted. Even if this were not the case, option (iii) is compatible with the national government having a special skill for reaching beneficiaries from low ng.votes regions and a similar capacity to tax all regions (Dixit and Londregan, 1996). In Peru, option (iii) is the most likely situation, given that in a rapidly evolving political setting, voters are usually short-sighted in their capacity to penalize the incumbent when it results in lower transfers to their region. In this regard, we expect that the traditional political cycle as conceived by Rogoff and Sibert (1988) may be contaminated by the opportunity to withdraw benefits from supporters and give them to political opponents immediately after the national government is elected.

Another point to consider is whether the degree of regional government support is relevant from the view point of the national government's strategy for staying in power. We hypothesize that political loyalty to regional parties (rg.votes) represents a threat to the 
national government as regional leaders become more popular. For example, Dickovick (2006) argues that municipal decentralization in Peru and other countries in Latin America is implicitly intended to weaken the intermediate level of government. Just as we expect that highly supported regional governments are given fewer transfers, we also expect that regional governments who hold the same party as the national president are likely to be particularly benefited. A dummy variable (D.REGNAT) for this case is included.

Among political variables, we assume that national authorities are sensitive to lobbying and pressure groups, but this channel of local demands is not easily observable. We distinguish lobbying (lobby), which expresses in the form of both organized and non-organized individuals who manage to represent their demands, from more radical ways to pressure the national government that result in visible political conflict at the regional level (conflict). Both forms of pressure may become a threat to the central government's ability to stay in power, so grants are likely to be sensitive to them. Additionally, regression models include time fixed effects that are expected to capture elements of the political cycle and a dummy variable to capture the effect of regions where the national government got more than $50 \%$ of the votes in the last presidential elections (D.50).

Regarding non-opportunistic reasons to assign grants, we expect that cost push and demand factors may affect the government's willingness to support more urbanized or densely populated regions (urban and dens). Similarly, the potential role of grants in compensating poor regions explains why the poverty rate (pov) might be relevant. A fair distribution of public tax revenues calls for more transfers to regions in which taxes per head are lower. Thus, high per capita regionally generated taxes (tax) and high per capita earmarked resources (canon) are likely to diminish financial support from the central government.

\section{Estimation approach}

The estimation strategy considers two econometric specifications of the general model. The first follows similar studies in using per capita transfers as the endogenous variable. Deviations from an equal per capita allocation arguably respond to factors cited above (see equation 1). Countries like Spain and Canada are explicit in equalizing per capita fiscal capacity across regions, which accounts for the local cost of public goods, fiscal equalization targets, some measurements of local needs, the jurisdictional tax base and a number of other indicators (Dahlby, 2008; Bosch, 2009).

The second specification focuses on the level of grants being allocated (designated using capital letters). All variables are presented in natural logs $(\ln )$. In contrast to the per capita model, this approach assumes that each year's allocation is based on the amount assigned the year before. An obvious challenge with this model is the potential correlation between the lagged level of our dependent variable, In (GRANT_I), and the error term. The simple ordinary least squares (OLS) estimation of this model leads to biased and inconsistent parameter estimates (see Greene, 2003).To deal with that, we use a generalized method of moments (GMM) estimation approach, which under reasonable assumptions results in consistent, asymptotically normal and asymptotically efficient estimators (Hansen, 1982). Both the remaining (non-endogenous) variables and the regions' fixed effects are all accounted for as instruments.

\section{The data}

The appendix provides a full list of the variables, with their definitions and sources. GRANT represents discretionary transfers from the central government to the regional governments $(O R)$. These are assigned annually by the Ministry of Economy and Finance. Data on this variable were taken from the corresponding annual budget, which is published on the Ministry's economic transparency website. The political discussion of the budget is based on a proposal from the national government, which becomes law on approval by the Congress. All data are expressed in the Peruvian currency, nuevos soles, at constant 2006 prices. The same source was used for the variable canon, which captures all regional transfers of earmarked resources. Budget items under this category were not available before 2007, so for 2004-2006 the variable was constructed by summing up all revenues (canon) from the exploitation of natural resources in each region. The variable tax was taken from the Office of the National Superintendent of Tax Administration, which is the administrative division responsible for collecting taxes. Formally, these data are collected regionally on the basis of taxpayers' fiscal address.

With regard to political variables, conflicts accounts for the number of regionally rooted initiatives intended to pressure the government to increase funding for specific areas. This variable was constructed from information provided by the Office of the Ombudsman, which classifies such conflicts regionally. The most 
common sources of lobbying include local (municipal) and regional authorities and public officers' unions, in particular teachers. Electoral variables were obtained from the National Elections Board, which manages electoral processes and records their results.

Sociodemographic variables were provided by the National Institute of Statistics and Informatics. Two basic data sets are collected by this bureau: the national census, whose last version dates to 2007, and the national household survey, which is carried out continuously. The bureau has published a poverty rate report annually since 1997 based on the household survey.
Finally, some caveats on the data are in order. First, despite our choice to use budget-based general resources, the figures are likely to overestimate actual regional expenditures. The budget itself, however, is assumed to capture political pressures fairly accurately. Second, the data used for the lobby variable are potentially biased downwards, as some lobby-related episodes may go unrecorded if they are not reported through an official note to the authorities in charge. The same holds for conflicts. Third, since some related series being considered are only available with a lag, the reported regressions only cover up to 2010 .

\section{V}

\section{Econometric results}

\section{Economic variables}

We expect transfers to be negatively affected by $\operatorname{tax}$ and canon in the per capita regression (see table 2). Although this is precisely the case, only canon appears to be significant. A feasible explanation is that grants from general resources are used as a compensatory device, whereby regions with poor natural endowments are given more transfers. The negative - albeit nonsignificant - sign of the estimated coefficient for tax probably reflects a similar role being played by general resources with respect to the general regional tax base. Nevertheless, this latter compensatory effect appears to be weaker. The regressions in levels provide slightly different results (see table 3 ). One important difference is that $\ln (C A N O N)$ appears to have a positive effect on the level of grants. This may reflect the fact that regions in which earmarked resource transfers are important (that is, a large value of $C A N O N$ ) also have larger demands on public infrastructure. Since the regions are responsible for this area of government, they should be given more resources to manage it. Nevertheless, demand for infrastructure is not necessarily related to the value of canon per capita, which explains why the signs of the estimated coefficients differ between tables 2 and 3 . In contrast to grants per capita, the level of taxes has a significant negative effect on the level of grants. This shows that regardless of the population, regions with a rich tax base receive fewer transfers.

\section{Sociodemographic variables}

The reported estimates show that pov is not significant in any of the regressions except GMM3 (see table 3). This is in line with the legal assignment of regional functions as defined in the constitutional reform on decentralization (Law 27680), the Decentralization Basis Law (Law 27783), and the Organic Law on Regional Governments (Law 27867), all passed in 2002. Regions are meant to promote regional economic development, regional investment and all services and activities related to regional responsibilities. Although these functions are ample, they do not explicitly make regions responsible for poverty alleviation programmes; this should be taken into account when interpreting the above results. While shared responsibilities are acknowledged in the provision of basic education, health services and employment promotion, the national government handles both the funding and the administration of poverty reduction programmes.

With regard to density, the positive coefficient in per capita estimates suggests that more densely populated regions probably have larger inter-jurisdictional externalities and congestion costs. This raises the per capita cost of regional public goods (the FE2 and FE3 regressions in table 2), but not the level of transfers (Litvack and Oates, 1971).This also explains the sign of urban. This variable records the extent to which the national population is unevenly distributed across regions. As this exacerbates the externality and congestion 
problems, more grants are likely to be allocated to highly urbanized regions. Results consistent with this argument are reported in both tables.

The variable pop captures a pure demand effect on regional public goods, and in so doing it affects grants positively. Since grants are divided by population in table 2, this variable is omitted from these regressions, whereas it is included in table 3 . The results show that a $1 \%$ increase in population leads to a rise in grants between $0.63 \%$ and $0.52 \%$ (the GMM2 and GMM3 regressions in table 3 ).

\section{Political economy variables}

With regard to political economy considerations, the variable lobby is significant only in the regressions in levels. Exactly the opposite occurs with conflicts. This is consistent with the nature of both variables. Since conflicts originate in pressure from well-identified groups that represent a permanent threat to national political stability, they are likely to lead to permanently higher transfers per capita over time (see table 2). Alternatively, the variable lobby is built on demands expressed to regional representatives by a variety of groups and people. Given its less specific origin, this variable poses no visible threat to national authorities. This is also in line with lobby being significant in the regressions in levels only, which implicitly means that increased lobbying does not necessarily lead to higher grants per capita.

We explore several measurements of voters' support for national and regional governments. As expected, the results in table 2 show that highly supported regional governments (large rg.votes) appear to receive fewer transfers per capita. This is in line with the national government's attempt to dampen potential political competition in a rather non-ideological context. A similar result is found with the regressions in levels (see table 3). Consistently with this finding, econometric evidence also suggests that more gains (in terms of new votes) are expected to be achieved by sending money to non-aligned regions. We find support for this assertion when we use $\mathrm{D} 5 \mathrm{O}+$ instead of the government support variables (FE2 in table 2 and GMM2 in table 3 ). This dummy variable appears to be particularly significant for explaining grants per capita (see table 2), in which case the results are the same even when ng.votes, rg.votes and D50+ are included together in the regression (FE3, FE4 and FE5). Moreover, grants are positively correlated with the regional constituency (GMM1 in table 3). Due to the high correlation between constituency and population, these regressors are not used together. A direct reading of GMM1 says that a $1 \%$ rise in constituency leads to almost a $0.4 \%$ increase in grants. We ran an additional regression to include the marginal voter variable (mar. votes) in FE4 and GMM4. This is done jointly with 50+ included in the regression. In both cases, marvotes is significant and has a positive coefficient in FE4, which runs counter to some of the evidence in favour of the swing-voter hypothesis. The interpretation of this is twofold. First, it suggests that swing voters are not located in regions where political support for the national government is close to $50 \%$, as some empirical studies point out. Second, it reveals that the national government attributes the highest political return to giving transfers to opposition regions. One feasible explanation is that taxing support groups, which in this case must be redefined as groups receiving lower transfers, does not lead to a significant loss of voters relative to the votes being gained by favouring opposition groups (Dixit and Londregan, 1998). While difficult to maintain in the long term, such a strategy can be given some credit at the beginning of the government's ruling period, as the relatively higher value of the 2007 time effect suggests (see table 2). A more time-consistent pattern can be observed by looking at how voters from opposition regions behave relative to those from supporting regions. Among the 12 opposition regions ${ }^{3}$ during the 2003-2006 period, only two kept the same regional government and ruling political party after the 2006 national election. This shows a highly volatile constituency, which suggests that opposition regions are the most likely to include indecisive voters, which in turn supports the swing-voter hypothesis.

Evidence of a classic political cycle may also be detected. During the period when President Toledo was in office (2004-2006), the first sample year (2004) records a lower value than the remaining time effects, which is also true for 2009. That is, years that are distant from presidential elections show smaller and less significant coefficients (see table 2).

\section{Hypotheses versus empirical evidence: a summary view}

Table 4 highlights our main findings by providing a summary of the hypotheses tested and the corresponding econometric results. The variables intended to detect opportunistic behaviour on the part of the national government are generally significant and exhibit theoretically sound effects. First, discretionary grants

\footnotetext{
3 Those with less than $50 \%$ support for the national government.
} 


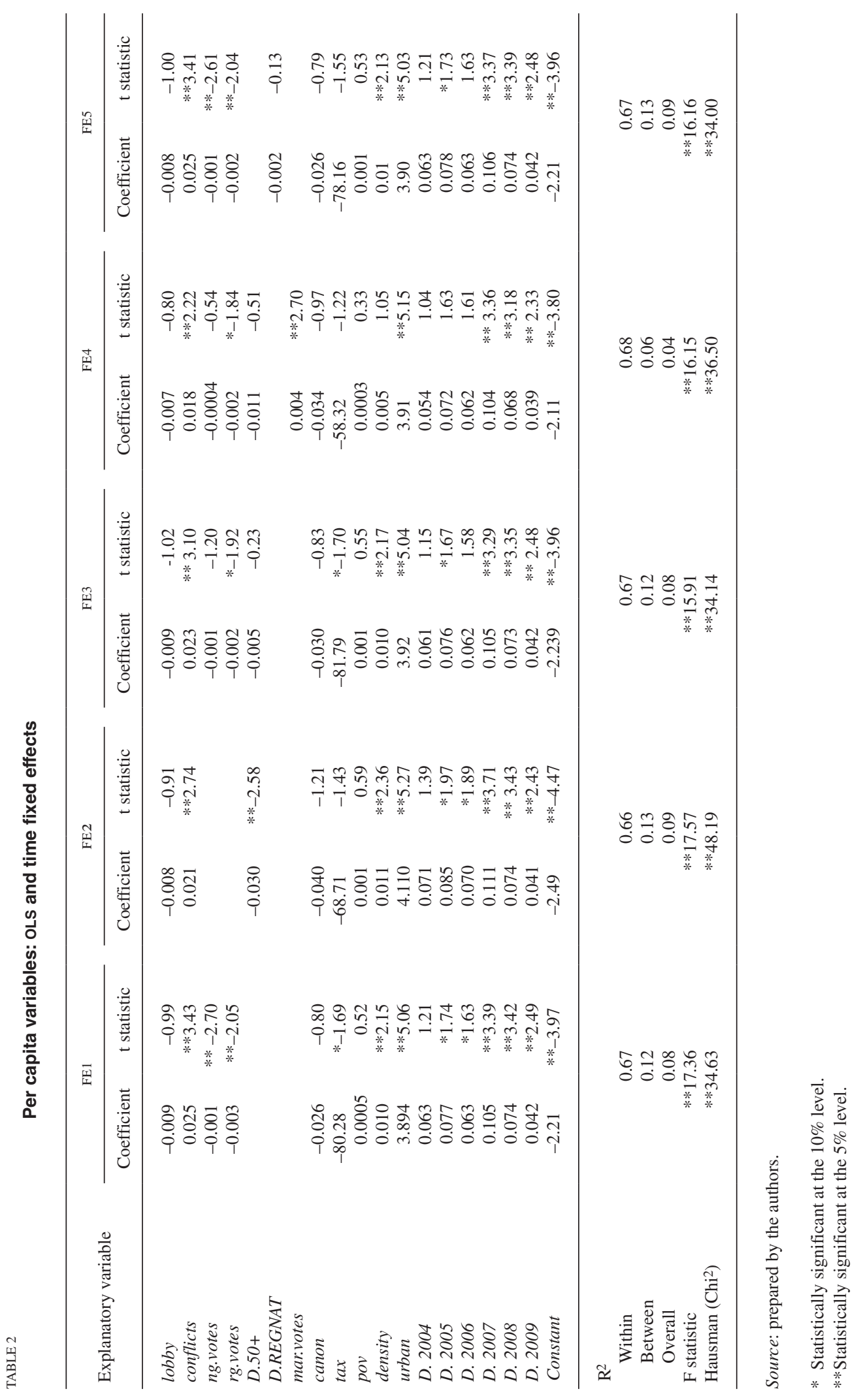




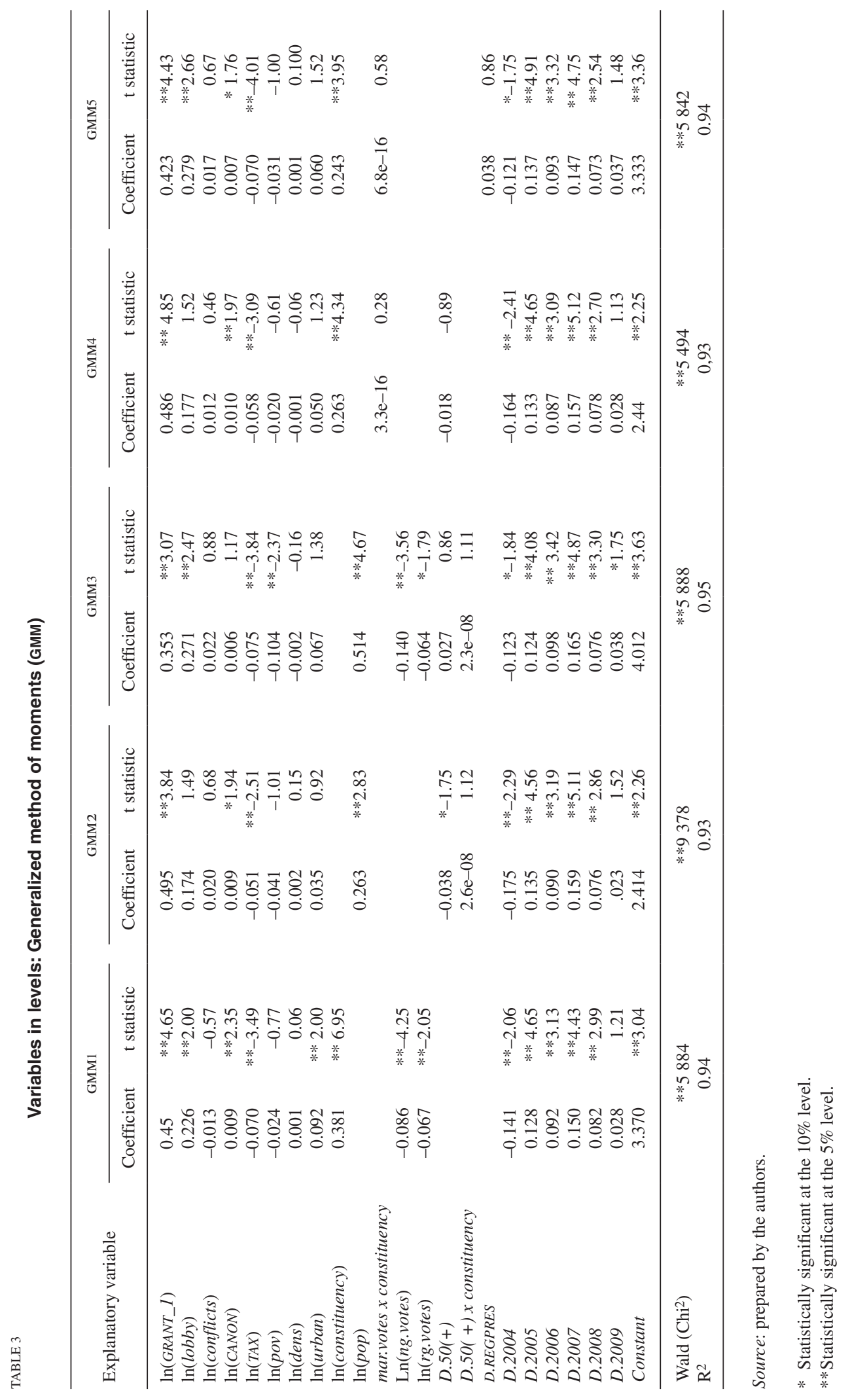


appear to be driven by swing voters. On the one hand, the aligned-region hypothesis is clearly rejected on account of the negative coefficients of ng.votes and D.50+, which indicate that non-aligned regions receive the most benefits. On the other, the composition of regional constituencies seems to be highly volatile (see above), which reinforces the assertion that opposition regions host the most indecisive voters in our sample. A second political economy finding is that regions in which the president in office is strongly supported by the local constituency receive fewer discretionary grants. The negative and significant $r$ g.votes coefficient supports this, providing evidence that popular regional leaders are likely to be seen as a political threat to the national government. A third piece of evidence confirms that lobbying (lobby) and interest groups (conflicts) matter. Fourth, we also find evidence of a political business cycle, as years close to presidential elections record higher and more significant time effects. Lastly, the lack of statistical significance of D.REGNAT, which stands as a proxy for the extent of ideological interaction between the national and regional tiers of government, may be interpreted as a sign that ideology does not rank high in the grant allocation criteria.
Normative considerations also play a significant role. As expected, population (pop), population density (density) and urbanization (urban) all affect grants positively. Nonetheless, poverty (pov) does not appear to be a factor in grant allocation, which is in line with the institutional role of the regions in Peru. Similarly, per capita mining taxes (canon) affect per head assignments negatively, as do taxes in the $\ln ($ GRANT) regressions. As stated above, the positive effect of canon on $\ln (G R A N T)$ may reflect the fact that regions receiving a high level of earmarked resources are likely to require more public investment.

Finally, some other feasible hypotheses are potentially testable beyond the scope of our database. A municipal-based empirical study on the subject matter would be a major contribution. Local governments in Peru are also given general resources, which are basically used to fund social programmes executed by the municipalities to fulfil a central government mandate. While they are smaller than regional grants, there is plenty of space for their allocation to be politically motivated. Another potentially interesting extension of this research hinges on how municipalities determine property tax collection, including who is to be charged and how intensive the tax collection effort is.

Expected effects and econometric results

\begin{tabular}{|c|c|c|c|c|}
\hline \multirow{2}{*}{ Variable } & \multicolumn{2}{|c|}{ Effect on grcap } & \multicolumn{2}{|c|}{ Effect on $\ln ($ GRANT $)$} \\
\hline & Expected & Estimated & Expected & Estimated \\
\hline lobby & + & NS & + & + \\
\hline conflicts & + & + & + & NS \\
\hline ng.votes & $?$ & - & $?$ & - \\
\hline rg.votes & - & - & - & - \\
\hline Constituency & & & + & + \\
\hline D. $50+$ & $?$ & - & $?$ & - \\
\hline D. $50+\times$ constituency & & & $?$ & NS \\
\hline marvotes & $?$ & + & $?$ & NS \\
\hline marvotes $\times$ constituency & & & + & NS \\
\hline canon & - & - & $?$ & + \\
\hline $\operatorname{tax}$ & - & NS & $?$ & - \\
\hline pov & $?$ & NS & $?$ & - \\
\hline density & + & + & + & NS \\
\hline рор & + & + & & \\
\hline urban & $?$ & + & $?$ & + \\
\hline D.REGNAT & + & NS & + & NS \\
\hline
\end{tabular}

Source: prepared by the authors.

Grcap: grants per capita.

NS: Not significant. 


\section{VI}

\section{Conclusions}

This research sheds light on the political economy of the regional allocation of discretionary grants in Peru. In contrast to similar empirical studies for other countries, we found that regions in which the national government has the lowest support generally receive the largest benefits. One feasible explanation for this trend, following Dixit and Londregan (1996), is that the national government may have a comparative advantage in targeting opposition groups, while shifting the cost of this political manoeuvre to supporting groups. This scenario is more likely to hold at the beginning of the government's ruling period, which is compatible with regression results. Nevertheless, the positive association between opposition regions and more volatile constituencies suggests than in the long term, the swing-voter hypothesis is valid.

Our results also indicate that the national government is sensitive to the size of the regional constituency and the potential danger of competition from powerful regional leaders, which is reflected in the low level of transfers to politically strong regional governments. When allocating transfers, the national government also appears to be sensitive to lobbying from private organized groups and regional conflicts. Normative considerations are also relevant. More discretionary funds are given to densely populated and urbanized regions and to regions with a lower tax base and fewer mining-related resources.

APPENDIX

Variable definitions and sources

\begin{tabular}{|c|c|c|}
\hline Variable & Definition & Source \\
\hline GRANT & Discretionary transfers to regions & $\begin{array}{l}\text { Economic transparency website of the Ministry of } \\
\text { Economy and Finance }\end{array}$ \\
\hline lobby & $\begin{array}{l}\text { Complaints sent by organized regional residents to the } \\
\text { national Congress }\end{array}$ & $\begin{array}{l}\text { Congress of the Republic of Peru and Ministry of } \\
\text { Economy and Finance }\end{array}$ \\
\hline conflicts & Number of regionally rooted regional conflicts & Office of the Ombudsman \\
\hline ng.votes & $\begin{array}{l}\text { [percentage of regional votes for the ruling national } \\
\text { government] x [regional constituency] }\end{array}$ & National Elections Board \\
\hline rg.votes & $\begin{array}{l}\text { [percentage of regional votes for the ruling regional } \\
\text { government] x [regional constituency] }\end{array}$ & National Elections Board \\
\hline Constituency & Regional constituency & National Elections Board \\
\hline D.50+ & $\begin{array}{l}\text { Dummy variable for regions with more than } 50 \% \\
\text { support for the national government }\end{array}$ & National Elections Board \\
\hline marvotes & $\begin{array}{l}\text { Marginal voter: Absolute value of [percentage of } \\
\text { regional support for the national government]- } 50\end{array}$ & National Elections Board \\
\hline D.REGNAT & $\begin{array}{l}\text { Dummy variable for the case in which the national and } \\
\text { the regional presidents belong to the same political party }\end{array}$ & National Elections Board \\
\hline canon & Earmarked resources per capita & $\begin{array}{l}\text { Economic transparency website of the Ministry of } \\
\text { Economy and Finance }\end{array}$ \\
\hline $\operatorname{tax}$ & Regionally generated taxes per capita & $\begin{array}{l}\text { Office of the National Superintendent of Tax } \\
\text { Administration }\end{array}$ \\
\hline pov & Regional population below the poverty line & National Institute of Statistics and Informatics \\
\hline density & Population density & National Institute of Statistics and Informatics \\
\hline рор & Regional population & National Institute of Statistics and Informatics \\
\hline urban & Degree of urbanization & National Institute of Statistics and Informatics \\
\hline
\end{tabular}

Source: prepared by the authors. 
Anderson, G. and R.D. Tollison (1988), "Democracy, interest groups, and the price of votes", Cato Journal, vol. 8, No. 1, Washington, D.C., CATO Institute.

Ansolabehere, S. and J.M. Snyder (2006), "Party control of state government and the distribution of public expenditures", The Scandinavian Journal of Economics, vol. 108, No. 4, Wiley.

Arrington, L.J. (1970), "Western agriculture and the new deal", Agricultural History, vol. 44, No. 4, Winter Park, Agricultural History Society.

Bensa, J. (2002), "El sistema electoral subnacional en Perú y Chile entre 1980 y 2002", Elecciones, No. 1, Lima, Oficina Nacional de Procesos Electorales.

Biswas, R., S. Marjit and V. Marimoutou (2010), "Fiscal federalism, state lobbying and discretionary finance: evidence from India", Economics \& Politics, vol. 22, No. 1, Wiley Blackwell.

Boex, J. and J. Martínez-Vázquez (2010), "The Determinants of the Incidence of Intergovernmental Grants: A Survey of the International Experience", Atlanta, Andrew Young School of Policy Studies, Georgia State University, unpublished.

Bosch, N. (2009), "El sistema de nivelación fiscal entre las comunidades autónomas", Revista de Estudios Regionales, Número extraordinario (VIII), Universidades Públicas de Andalucía.

Buchanan, J. (1950), "Federalism and fiscal equity", American Economic Review, vol. 40, No. 4, Nashville, Tennessee, American Economic Association.

Carranza, L., J. Chávez and J. Valderrama (2007), "La economía política del proceso presupuestario: El caso peruano", Working Paper, No. CS-102, Washington, D.C., Inter-American Development Bank.

Case, A. (2001), "Election goals and income redistribution: recent evidence from Albania", European Economic Review, vol. 45, No. 3, Amsterdam, Elsevier.

Castells, A. and A. Solé-Ollé (2005), "The regional allocation of infrastructure investment: the role of equity, efficiency and political factors", European Economic Review, vol. 49, No. 5, Amsterdam, Elsevier.

Couch, J.F. and W. Shughart II (1998), The Political Economy of the New Deal, Cheltenham, The Independent Institute.

Cox, G. (2010), "Swing voters, core voters and distributive politics", Political Representation, I. Shapiro and others (eds.), Cambridge, Cambridge University Press.

Cox, G. and M. McCubbins (1986), "Electoral politics as a redistributive game", Journal of Politics, vol. 48, No. 2, Cambridge, Cambridge University Press.

Dahlberg, M. and E. Johansson (2002), "On the vote-purchasing behavior of incumbents governments", American Political Science Review, vol. 96, No. 1, Cambridge, Cambridge University Press.

Dahlby, D. (2008), "The Canadian federal-provincial fiscal equalization system", CESifo DICE Report, vol. 6, No. 1, Munich, University of Munich.

Díaz-Cayeros, A. (2008), "Electoral risk and redistributive politics in Mexico and the United States", Studies in Comparative International development, vol. 43, No. 2, Springer.

Díaz-Cayeros, A., F. Estévez and B. Magaloni (2008), "Strategies of vote buying: social transfers, democracy and welfare in Mexico", Stanford, Stanford University.

Dickovick, J.T. (2006), "Municipalization as central government strategy: central-regional-local politics in Peru, Brazil, and South Africa", Publius: The Journal of Federalism, vol. 37, No. 1, Oxford University Press.

Dixit, A. and J. Londregan (1998), "Ideology, tactics, and efficiency in redistributive politics", The Quarterly Journal of Economics, vol. 113, No. 2, Oxford, Oxford University Press, May.
(1996), "The determinants of success of special interests in redistributive politics", The Journal of Politics, vol. 58, No. 4, Cambridge, Cambridge University Press.

Drazen, A. (2000), Political Economy in Macroeconomics, Princeton, Princeton University Press.

Gamkhar, S. and H. Ali (2007), "Political economy of grant allocations: the case of federal highway demonstration grants", Publius: The Journal of Federalism, vol. 38, No. 1, Oxford University Press.

Gonçalves, L. (2010), "Determinants of the assignments of EU funds to Portuguese municipalities", Public Choice, forthcoming.

Graham, C. and C. Kane (1998), "Opportunistic government or sustaining reform: electoral trends and public expenditure patterns in Peru 1990-1995”, Latin American Research Review, vol. 33, No. 1, Pittsburgh, Latin American Studies Association.

Greene, W. (2003), Econometric Analysis, New Jersey, Prentice Hall.

Grossman, P. (1994), "A political theory of intergovernmental grants", Public Choice, vol. 78, No. 3-4, Springer.

Hanes, N. (2007), "Temporary grant programmes in Sweden and central government behavior", European Journal of Political Economy, vol. 23, No. 4, Amsterdam, Elsevier.

Hansen, L.P. (1982), "Large sample properties of generalized method of moments estimators", Econometrica, vol. 50, No. 4, New York, The Econometric Society.

Inman, R. (1988), "Federal assistance and local services in the United States: the evolution of a new federalist order", Fiscal Federalism: Quantitative Studies, H. Rosen (ed.), Chicago, University of Chicago Press.

Johansson, E. (2003), "Intergovernmental grants as a tactical instrument: empirical evidence from Swedish municipalities", Journal of Public Economics, vol. 87, No. 5-6, Amsterdam, Elsevier.

King, D. (1991), "Grants as source of local government finance", Local Government: An International Perspective, J. Owens and G. Panella (eds.), Amsterdam, North Holland.

Letelier, L. (2012), "Teoría y práctica de la descentralización fiscal", Santiago, Chile, Ediciones Católica de Chile.

Lindbeck, A. and J. Weibull (1993), "A model of political equilibrium in a representative democracy", Journal of Public Economics, vol. 51, Amsterdam, Elsevier.

(1987), "Balanced-budget redistribution as the outcome of political competition", Public Choice, vol. 52, No. 3, Springer.

Litvack, J. and W. Oates (1971), "Group size and the output of public goods: theory and application to state-local finance in the United States", Public Finance, vol. 25, No. 2.

Milligan, K. and M. Smart (2005), "Regional grants as pork barrel politics", CESifo Working Paper, No. 1453, Munich, CESifo Group Munich.

Musgrave, R. (1958), The Theory of Public Finance, New York, McGraw-Hill.

Oates, W. (1972), Fiscal Federalism, New York, Harcourt Brace Jovanovich.

Olson, M. (1965), The Logic of Collective Action, Cambridge, Harvard University Press.

Porto, A. and P. Sanguinetti (2001), "Political determinants of intergovernmental grants: evidence from Argentina", Economics and Politics, vol. 13, No. 3, Wiley Blackwell.

Reading, D.C. (1973), "New deal activity and the states, 1933 to 1939", Journal of Economic History, vol. 33, No. 4, Cambridge, Cambridge University Press.

Rogoff, K. (1990), "Equilibrium political budget cycles", American Economic Review, vol. 80, No. 1, Nashville, Tennessee, American Economic Association.

Rogoff, K. and A. Sibert (1988), "Elections and macroeconomic policy cycles", Review of Economic Studies, vol. 55, No. 1, Oxford, Oxford University Press. 
Segura-Ubiergo, A. (2007), "Political instability, regime change, and late economic reform in non-welfare state", The Political Economy of the Welfare State in Latin America. Globalization, Democracy and Developement, Washington, D.C., International Monetary Fund.

Schady, N.R. (2000), "The political economy of expenditures by the Peruvian social fund (FONCODES) 1991-95", American Political Science Review, vol. 94, No. 2, Washington, D.C., American Political Science Association.

Solé-Ollé, A. and P. Sorribas (2008), "The effects of partisan alignment on the allocation of intergovernmental transfers. Differences-indifferences estimates for Spain", Journal of Public Economics, vol. 92, No. 12, Amsterdam, Elsevier.
Tanaka, Martín (2002), "La dinámica de los actores regionales y el proceso de descentralización: ¿el despertar del letargo?”, Working Paper, No. 125 Lima, Peruvian Studies Institute.

Vega, J.C. (2008), "Análisis del proceso de descentralización fiscal en el Perú”, Working Paper, No. 266, Lima, Catholic University of Peru.

Wallis, J. (1998), "The political economy of new deal spending revisited, again: with and without Nevada", Explorations in Economic History, vol. 35, No. 2, Amsterdam, Elsevier.

Wright, G. (1974), "The political economy of new deal spending, an econometric analysis", The Review of Economics and Statistics, vol. 56, No. 1, Cambridge, Massachusetts, The MIT Press. 